https://doi.org/10.52058/2786-4952-2021-4(4)-223-235

Ненько Юлія Петрівна доктор педагогічних наук, професор, завідувач кафедри іноземних мов, Черкаський інститут пожежної безпеки імені Героїв Чорнобиля Національного університету цивільного захисту України, вул. Онопрієнка, 8, м. Черкаси, 18034, e-mail: nenko_yuliia@ chipb.org.in, https://orcid.org/0000-0001-7868-0155

Іващенко Оксана Алімівна кандидат педагогічних наук, доцент, доцент кафедри іноземних мов, Черкаський інститут пожежної безпеки імені Героїв Чорнобиля Національного університету цивільного захисту України, вул. Онопрієнка, 8, м. Черкаси, 18034, e-mail: ivashchenko_oksana@ chipb.org.in, https://orcid.org/0000-0003-0978-3075

\title{
ОСОБЛИВОСТІ ІНШОМОВНОЇ ПІДГОТОВКИ БАКАЛАВРІВ ВІДОМЧИХ ЗАКЛАДІВ ВИЩОЇ ОСВІТИ ДЕРЖАВНОЇ СЛУЖБИ УКРАЇНИ З НАДЗВИЧАЙНИХ СИТУАЦІЙ (НА ПРИКЛАДІ ОСВІТНЬО- ПРОФЕСІЙНОЇ ПРОГРАМИ «ЦИВІЛЬНИЙ ЗАХИСТ»)
}

Анотація. У статті розглянуто проблему взаємозв'язку іншомовної комунікативної підготовки та майбутньої професійної діяльності здобувача першого (бакалаврського) рівня вищої освіти за спеціальністю 263 Цивільна безпека в галузі знань 26 Цивільна безпека за освітньо-професійною програмою «Цивільний захист». Доведено, що іншомовна комунікативна компетентність становить важливу й невіддільну складову професійної компетентності майбутнього офіцера в контексті його/іï можливої участі міжнародних пошуково-рятувальних операціях, операціях із ліквідації наслідків надзвичайних ситуацій, мультинаціональних професійних тренуваннях чи навчаннях тощо. Вивчено та проведено порівняльний аналіз навчальних планів, робочих програм та силабусів нормативної дисципліни «Іноземна мова» відомчих закладів вищої освіти Державної служби України (Черкаський інститут пожежної безпеки імені Героїв Чорнобиля Національного університету цивільного захисту України, Львівський університет безпеки життєдіяльності, Національний університет цивільного захисту України) та цивільних закладів освіти (Національний технічний університет «Дніпровська політехніка», Національний авіаційний університет, Національний університет «Львівська політехніка»). 3'ясовано компетентності та програмні результати навчання в контексті іншомовної підготовки, що відповідають дескрипторам Національної рамки кваліфікацій та відповідному Стандарту вищої освіти України. Простежено обмежений обсяг аудиторних годин, виокремлених на нормативну навчальну дисципліну 
«Іноземна мова» та відсутність можливості у здобувача освіти обрати дисципліну «Іноземна мова» як вибіркову освітню компоненту в переважній більшості закладів вищої освіти.

Ключові слова: іншомовна професійна комунікація, курсант, підготовка, заклад вищої освіти, готовність до іншомовної комунікації.

Nenko Yuliia Petrivna Doctor of Educational Sciences, Professor, Head of Foreign Languages Department, Cherkasy Institute of Fire Safety named after Chornobyl Heroes of the National University of Civil Defense of Ukraine, Onoprienka St., 8, Cherkasy, 18034, e-mail: nenko_yuliia@chipb.org.in, https://orcid.org/0000-0001-7868-0155

Ivashchenko Oksana Alimivna Candidate of Educational Sciences, Associate Professor, Associate Professor at Foreign Languages Department, Cherkasy Institute of Fire Safety named after Chornobyl Heroes of the National University of Civil Defense of Ukraine, Onoprienka St., 8, Cherkasy, 18034, e-mail: ivashchenko_oksana@chipb.org.in, https://orcid.org/0000-0003-0978-3075

\section{PECULIARITIES OF FOREIGN LANGUAGE TRAINING OF BACHELORS AT DEPARTMENTAL INSTITUTIONS OF HIGHER EDUCATION OF THE STATE EMERGENCY SERVICE OF UKRAINE (ON THE EXAMPLE OF THE EDUCATIONAL-PROFESSIONAL PROGRAM "CIVIL PROTECTION")}

Abstract. The article considers the problem of interrelation of foreign language communicative training and future professional activity of the applicant of the first (bachelor's) level of higher education in the specialty 263 Civil security in the field of knowledge 26 Civil security in the educational-professional program "Civil protection". It is proved that foreign language communicative competence is an important and inseparable component of the professional competence of the future officer in the context of his / her possible participation in international search and rescue operations, emergency response operations, multinational professional training or exercises, etc. The comparative analysis of curricula, work programs and syllabi of the normative discipline "Foreign language" at departmental institutions of higher education of the State Emergency Service of Ukraine (Cherkasy Institute of Fire Safety named after Chornobyl Heroes of the National University of Civil Defense of Ukraine, Lviv University of Life Activity Safety, National University of Civil Defense of Ukraine) and civilian educational institutions (National Technical University "Dnipro Polytechnic", National Aviation University, National University "Lviv Polytechnic"). The competencies and program learning outcomes in the context of foreign language training, which correspond to the descriptors of the National Qualifications Framework and the relevant Standard of Higher Education of Ukraine, have been clarified. The limited amount of classroom hours allocated to the normative discipline "Foreign 
Language" and the lack of opportunity for students to choose the discipline "Foreign Language" as an optional educational component in the vast majority of higher education institutions has been proved.

Keywords: foreign language professional communication, cadet, training, institution of higher education, readiness for foreign language communication.

Постановка проблеми. Масштабні надзвичайні ситуації, катастрофи та інші кризи, що відбуваються останні десятиліття, не визнають державних кордонів і виникають раптово. Масштаб людських страждань, спричинених цими подіями, величезний; вони завдають шкоди багатьом аспектам людського життя - здоров'ю, безпеці, житлу, доступу до їжі, води та інших життєво важливих речей. Відтак, нагальною $є$ фаховість та підготовленість особового складу аварійно-рятувальних служб для ефективного й скоординованого реагування на ту чи іншу катастрофу чи кризу.

Пошуково-рятувальні підрозділи ДСНС України беруть активну участь у міжнародних операціях із ліквідації наслідків надзвичайних ситуацій під егідою $\mathrm{OOH}$, міжнародних організацій, а також на двосторонній основі.

У контексті євроінтеграції та євроатлантичної інтеграції відбувається постійне налагодження взаємодії з відповідними структурами інших держав і міжнародних організацій, що відповідають за попередження i ліквідацію наслідків надзвичайних ситуацій, відпрацювання спільних планів і механізмів реалізації спільних дій у випадку природних та техногенних катастроф; налагодження обміну інформацією і досвідом із відповідних проблем. Серед ключових напрямків співробітництва виокремлено практичні програми взаємодії зі структурами Організації Об'єднаних Націй, Ради Європи та Європейської Комісії, НАТО, інших організацій на кшталт масштабних міжнародних польових навчаннях 3 реагування на надзвичайні ситуації «EU MOLDEX 2017», організованих в рамках Програми із запобігання, готовності та реагування на катастрофи природного і техногенного характеру для країн Східного партнерства "PPRD East II"; навчання "Rescue Days Ukraine 2019" 3 підвищення рівня професійної підготовки фахівців ДСНС до реагування на дорожньо-транспортні пригоди із залученням тренерів з Республіки Польща, Німеччини та Франції тощо. Метою вказаних заходів $є$ відпрацювання порядку взаємодії під час запобігання та реагування на надзвичайні ситуації природного і техногенного характеру, залучення пожежних, рятувальних, медичних підрозділів та формування радіаційного, хімічного і біологічного захисту, надсилання запиту для залучення міжнародної допомоги тощо [1].

Водночас за останні років акцент із гуманітарного реагування на надзвичайні або кризові ситуації та екстреного надання допомоги (на національному чи міжнародному рівні) змістився на стратегії та дії, які передували катастрофі задля пом'якшення наслідків цих подій для громад та збереження людського життя та майна. Стає все більш очевидним, що, хоча гуманітарні зусилля залишаються важливими й потребують постійної уваги, 
Журнал«Герспективита інновації науки

(Серія«Гедагогіка», Серія «Гиихологія», Серія «Медицинв»

№4(4) 2021

програми фахової підготовки офіцерів для професійної комунікації іноземною мовою в міжнародних миротворчих, антитерористичних, пошуково-рятувальних операціях $\epsilon$ одним із найефективніших інструментів для сприяння та підтримки міжнародного миру та безпеки [2] й мають вирішальне значення для зменшення наслідків надзвичайних ситуацій, катастроф та інших криз, а отже, необхідні для досягнення та захисту сталого розвитку [3].

Аналіз останніх досліджень i публікацій. Дослідження готовності особового складу до іншомовного спілкування відносно рідко проводять у військових організаціях, які $є$ подекуди ієрархічними та формалізованими. Важливі аспекти формування та розвитку готовності особового складу ДСНС України до професійно орієнтованої комунікативної діяльності, у тому числі й іншомовної, висвітлюються такими українськими вченими як Н. Вовчаста [4], В. Ворона та В. Яригіна [2], Ю. Ненько [5], К. Шихненко [6] та ін.

Авторська позиція Ю. Ненько щодо змістового наповнення терміну «готовність до професійно орієнтованої комунікативної діяльності» висвітлюється таким чином: «інтегративний довготривалий стан особистості та логічний результат спеціального навчання, виховання та самоосвіти, що містить аксіологічні, знаннєві та діяльнісні компоненти як поєднання знань, умінь та професійно важливих якостей, що забезпечують повноцінну здатність випускника вищої освіти ДСНС України вести ефективну професійно орієнтовану комунікативну діяльність у професійній сфері [5].

Дослідниця Н. Вовчаста вважає поняття «професійна іншомовна готовність майбутніх фахівців цивільного захисту» ширшим, ніж «готовність до професійного іншомовного спілкування» та розуміє досліджуване поняття як «інтегративне утворення як результат професійної іншомовної підготовки, що має відповідну структуру (загальнонауковий контекст), що уможливлює здатність до іншомовного спілкування та взаємодії (іншомовний контекст), передбачає практичне застосування іншомовних умінь та навичок відповідно до вимог професійної діяльності (професійний контекст), зумовлює прагнення до удосконалення та розширення професійної іншомовної підготовки (андрагогічний контекст)» [4].

Однак теоретичні напрацювання вітчизняних дослідників не систематизовані, не закріплені на законодавчому та методологічному рівнях, а отже не достатньо впровадженні в освітній процес у відомчих закладах вищої освіти.

Мета статті - дослідження особливостей іншомовної підготовки у відомчих закладах вищої освіти в контексті формування готовності майбутніх офіцерів до участі в міжнародних мультинаціональних операціях; аналіз навчально-методичних документів (навчальних планів, робочих програм, силабусів тощо) у контексті формування готовності особового складу до міжособистісної взаємодії та іншомовної комунікації задля розширення базових професійних компетентностей персоналу відповідних служб за рахунок 
більшого акценту не на мовних навичках, а саме на їхній готовності до професійного спілкування іноземною мовою в міжнародних миротворчих, антитерористичних, пошуково-рятувальних операціях. Обидва аспекти, звичайно, тісно пов’язані, та потребують обопільного дослідження.

Виклад основного матеріалу. Шестирічна стратегія ВОО3 для сектору охорони здоров'я та розвитку потенціалу громад [3, с. 8] трактує готовність до надзвичайних ситуацій як «програму довгострокової діяльності, метою якої $\epsilon$ зміцнення загальної спроможності країни чи громади ефективно керувати всіма видами надзвичайних ситуацій та забезпечити впорядкований перехід від надання допомоги через відновлення та повернення до сталого розвитку».

Готовність до надзвичайних ситуацій традиційно зосереджується на наданні невідкладної допомоги населенню, розробленні планів реагування на надзвичайні ситуації, а також регулярному моніторингу та оцінюванню ефективності цих заходів. У більшості країн політична прихильність, фінансові та людські ресурси зосереджені переважно на цих короткострокових заходах [3, с. 9].

Хоча нарощування потенціалу для гуманітарного реагування продовжує залишатися пріоритетом для всіх країн, провідні науковці та практичні працівники наголошують (можливо під впливом тяжкості та частоти катастроф i конфліктів за останнє десятиліття), що необхідно приділяти набагато більшу увагу впровадженню проактивних стратегій і більш комплексному підходу до створення національного потенціалу щодо готовності та реагування на надзвичайні ситуації. Міжнародні ініціативи гуманітарної спільноти все більше спрямовані на підтримку цієї мети. Завдання полягає в тому, щоб створити такі систематичні можливості, як законодавство, плани, механізми та процедури координації, інституційні можливості та фінансування, кваліфікований персонал, інформаційний обмін, а також обізнаність та участь громадськості, які можуть вимірно зменшити майбутні ризики та втрати. Окрема увага акцентується на необхідності навчання персоналу на всіх рівнях і в усіх секторах.

Однак аспект, який часто нехтують або применшують, - це проблема, викликана міжнародним виміром таких масштабних рятувальних місій: мова. Всупереч статусу англійської мови lingua franca, ï̈ вивчення у відомчих закладах вищої освіти все ще не набуло належного рівня та значущості. Проте цілком очевидно, що непорозуміння можуть мати далекосяжні наслідки, особливо в надзвичайних ситуаціях із критичним часом, які вимагають швидкої оцінки та прийняття рішень, і в яких перекладачі рідко доступні.

В епоху постійного вдосконалення технологій перекладу фахівці визнають як переваги, так і недоліки таких технологій, i прагнуть оптимізувати їхнє використання, де це доречно, поєднуючи їх 3 людським досвідом. Водночас зауважимо, що у сценаріях стихійного лиха може бути пошкоджена базова комунікаційна інфраструктура, включно 3 джерелами живлення, що робить повну залежність від технологій неспроможною. Хоча рятувальники, залучені до 
Журнал«Герспективитаінновації науки»

(Серія«Гедагогіка», Серія«Гцихологія», Серія«Медицинв»

№4(4) 2021

міжнародних операцій, повинні вміти належним чином застосовувати технології, часто саме міцні лінгвістичні та культурні навички рятують ситуацію в кризових сценаріях.

У відомчих закладах ДСНС України цінність знання іноземних мов не завжди цінується, а тривалість часу, необхідного для опановування мови, а також наявність безкоштовних онлайн-інструментів для перекладу можуть бути факторами зниження аудиторних годин, виокремлених на таку освітню компоненту як навчальна дисципліна «Іноземна мова».

Розглянемо на прикладі освітньо-професійної програми «Цивільний захист» першого рівня вищої освіти за спеціальністю 263 Цивільна безпека галузі знань 26 Цивільна безпека, пропоновану Черкаським інститутом пожежної безпеки імені Героїв Чорнобиля Національного університету цивільного захисту України. Основним фокусом освітньої програми та спеціалізації визначено «спеціальну освіту та професійну підготовку 3 питань захисту населення, територій, навколишнього природного середовища та майна від надзвичайних ситуацій шляхом попередження і ліквідації таких ситуацій» [7].

Відповідно до здобутої освітньої кваліфікації бакалавр здатний виконувати професійні роботи за професіями, зазначеними у ДК 003:2010 Національний класифікатор України. Класифікатор професій, а саме: «Черговий оперативний (загону, центрального командно-диспетчерського пункту, оперативнорятувальної служби цивільного захисту та ін.)», «Інспектор державний з питань цивільного захисту та техногенної безпеки», «Фахівець оперативно-рятувальної служби цивільного захисту», «Начальник караулу (зміни, поста) оперативнорятувальної служби цивільного захисту», «Начальник караулу (зміни, поста) частини (сфера цивільного захисту)».

Опанування зазначеної освітньо-професійної програми передбачає набуття випускниками з-поміж інших таких загальних компетентностей: здатність спілкуватися державною мовою як усно, так і письмово; здатність спілкуватися іноземною мовою; навички міжособистісної взаємодії; здатність працювати як в команді, так і автономно.

До програмних результатів розробники освітньо-професійної програми відносять: розробляти тексти та документи 3 питань професійної діяльності, спілкуватися українською професійною мовою; читати й розуміти фахову іншомовну літературу, використовуючи іiі у соціальній і професійній сферах; демонструвати культуру мислення та виявляти навички щодо організації культурного діалогу на рівні, необхідному для професійної діяльності.

Зазначені компетентності та програмні результати навчання відповідають дескрипторам Національної рамки кваліфікацій [8] та Стандарту вищої освіти України за першим (бакалаврським) рівнем вищої освіти в галузі знань 26 Цивільна безпека, спеціальність 263 - Цивільна безпека [9].

В контексті іншомовної підготовки виокремлено обов'язкову компоненту освітньо-професійної програми «Цивільний захист»-«Іноземна мова», на 
яку виділено 3 кредити ЄКТС.

Згідно з силабусом, метою навчальної дисципліни $є$ формування базового рівня знань, навичок i вмінь здобувача, достатнього для елементарної комунікативної спроможності у сфері професійної діяльності [10].

У результаті вивчення дисципліни «Іноземна мова» у Черкаському інституті пожежної безпеки імені Героїв Чорнобиля Національного університету цивільного захисту України здобувач вищої освіти повинен отримати:

знання про:

•основні правила читання та орфографії;

•загальновживану й професійну лексику;

•базовий лексичний мовний матеріал по темах, передбачених курсом;

•базову нормативну граматику;

•елементарні синтаксичні та стилістичні особливості комунікації у сфері професійної діяльності;

уміння/навички:

•читати тексти з професійної тематики та здійснювати пошук інформації;

• розуміти основні ідеї текстів за фахом;

-користуватися різними видами словників та довідковою літературою;

•робити усні повідомлення на теми, запропоновані програмою;

-граматично правильно оформлювати висловлювання відповідно до комунікативної ситуації.

Навчальна дисципліна «Іноземна мова» вивчається на першому курсі, коли майбутні фахівці проходять період адаптації до умов навчання та набувають лише фрагментарних знань зі спеціальних професійних дисциплін. Попри достатньо широкий спектр пропонованих до вивчення тем («Особисті дані», «Розпорядок дня», «Аварійні служби», «Професія вогнеборця», «Історія пожежогасіння», «Природні катастрофи»), обмежена кількість аудиторних годин - 36 годин та обмежене знання професійної термінології, лімітоване знання практичних аспектів майбутньої діяльності не дозволяють повною мірою сформувати повноцінну готовність до участі в мультинаціональних міжнародних рятувальних місіях. Відтак, мова не йде про ефективне формування готовності до професійної іншомовної комунікації.

Таку ж освітньо-професійну програму пропонують до вивчення у Національному університеті цивільного захисту України (м. Харків), а компетентності, програмні результати та освітні компоненти й аудиторні години, виділені на мовні дисципліни, $є$ аналогічними.

Згідно з силабусом, метою викладання дисципліни «Іноземна мова»у Національному університеті цивільного захисту України за освітньопрофесійною програмою «Цивільний захист» визначено підготовку фахівців, здатних опрацьовувати професійно-орієнтовані іншомовні (друковані та електронні) джерела та здійснювати комунікацію у виробничих умовах під час усного та письмового спілкування [11]. 
Журнал«Герспективитаінновації науки»

(Серія«Гедагогіка», Серія«Гцихологія», Серія«Медицинв»

№4(4) 2021

До основних завдань дисципліни розробники відносять такі:

- навчити майбутніх фахівців за допомогою відповідних методів здійснювати ознайомче та пошукове читання;

-використовувати лексико-граматичний мінімум у певній галузі та іншомовні (друковані та електронні) джерела із застосуванням прийомів i методів письмового (комп'ютерного) спілкування та відповідних методів оформлення ділової документації;

-під час усного та письмового спілкування за допомогою відповідних методів застосовувати компоненти соціолінгвістичної компетенції для досягнення взаємного порозуміння.

У результаті вивчення навчальної дисципліни «Іноземна мова» здобувач вищої освіти повинен отримати:

знання:

•професійно-орієнтованого лексико-граматичного мінімуму;

•особливостей фахової термінології;

-лексичного мінімуму комп'ютерних (інформаційних) технологій;

- синтаксичних, семантичних та фонетичних правил й закономірностей іноземної мови;

•вимог до усного й писемного професійного мовлення;

- структури діалогу загальнонаукового характеру;

- мовленнєвого етикету спілкування іноземною мовою: моделі звертання, ввічливості, вибачення, погодження тощо;

уміння:

• розробляти тексти та документи з питань професійної діяльності,

- спілкуватися іноземною мовою;

-читати й розуміти фахову іншомовну літературу, використовуючи іiі у соціальній і професійній сферах;

-демонструвати культуру мислення та виявляти навички щодо організації культурного діалогу на рівні, необхідному для професійної діяльності [11].

Відмінністю $є$ й тематика навчальних дисциплін, зокрема «Іноземна мова». Так, до вивчення пропонуються такі теми: «Служба цивільного захисту в Україні та країні, мова якої вивчається», «Види та причини виникнення природних катастроф», «Мовленнєвий етикет спілкування», «Організація профілактичної роботи», «Лексичний мінімум основ міжкультурної свідомості з визначенням взаємостосунків і взаємовідносин», «Види та причини виникнення промислових катастроф», «Граматика для усного викладу інформації», «Прилади пожежогасіння», «Засоби індивідуального захисту рятувальників», «Вибухи. Класифікація вибухів», «Електронні іншомовні джерела», «Інженерна техніка та iii застосування при проведенні аварійно-рятувальних робіт», «Сайти міжнародних організацій цивільного захисту та організацій країни, мова якої вивчається», «Ліквідація пожеж та наслідків надзвичайних ситуацій», 


\section{Журнал«Герспективита іноваціїнауки»}

«Комп'ютерний переклад іншомовної інформації», «Тероризм та засоби безпеки», «Мовно-комунікативний рівень проведення презентацій», «Міжнародна взаємодія з питань захисту території та населення від наслідків надзвичайних ситуацій» [11].

У Львівському університеті безпеки життєдіяльності також можна опанувати освітньо-професійну програму «Цивільний захист». Однак розробники цієї програми вже виділяють більше кредитів на іншомовну підготовку майбутніх офіцерів, збільшивши кількість кредитів ЄКТС до 4,5 (64 аудиторних години), що вочевидь робить таку підготовку більш ефективною.

Варто зауважити, що окрім відомчих закладів вищої освіти Державної служби України 3 надзвичайних ситуацій (Черкаський інститут пожежної безпеки імені Героїв Чорнобиля Національного університету цивільного захисту України, Львівського університету безпеки життєдіяльності та Національного університету цивільного захисту України) освітньо-професійну програму «Цивільний захист» для першого (бакалаврського) рівня вищої освіти за спеціальністю 263 Цивільна безпека галузі знань 26 Цивільна безпека пропонують також і цивільні заклади вищої освіти. Вважаємо за необхідне розглянути такі програми в контексті іншомовної підготовки фахівців.

Так, Національний технічний університет «Дніпровська політехніка» у 2019 р. на іншомовну підготовку здобувача першого (бакалаврського) рівня вищої освіти за освітньо-професійною програмою «Цивільний захист» виділяє нормативну навчальну дисципліну «Іноземна мова для професійної діяльності», пропонуючи на вибір одразу три мови: англійську, німецьку, французьку загальним обсягом 6 кредитів ЄКТС. Здобувачі опановують іноземну мову протягом чотирьох послідовних семестрів - 3 першого по четвертий включно та завершують іï вивчення складанням екзамену [12]

Аналогічну освітньо-професійну програму можна опанувати й в Національному авіаційному університеті. Окрім нормативної навчальної дисципліни «Іноземна мова» (загальним обсягом 4 кредити СКТС), розробники програми серед вибіркових освітніх компонент пропонують «Іноземну мову за професійним спрямуванням», «Іноземну мову спеціальності» та «Іноземну мову за фахом» загальним обсягом 8 кредитів СКТС кожна [13].

Національний університет «Львівська політехніка» за аналогічною освітньопрофесійною програмою виділяє 9 кредитів СКТС на опанування обов'язкової навчальної дисципліни «Іноземна мова за професійним спрямуванням», яке відбувається протягом трьох послідовних семестрів [14].

Висновки. Дослідження освітньо-професійних програм «Цивільний захист», Стандарту вищої освіти України та інших нормативних документів свідчить про усвідомлене розуміння англомовної підготовки як необхідної компоненти системи професійної підготовки фахівців у сфері цивільного захисту. Формально навчання здійснюється із застосуванням спеціальних форм та методів, що відбивають специфіку конкретної спеціальності, відповідно до 
Журнал«Герспективитаінноваціїнауки

(Серія«Гедагогіка», Серія«Гцихологія», Серія«Медицинв»

№4(4) 2021

вимог нормативних документів ДСНС України, у тісному взаємозв'язку 3 профільними фаховими дисциплінами. Зміст програм 3 нормативної дисципліни «Іноземна мова» спрямований на ефективне опанування термінологічного апарату для подальшого використання мови в ситуаціях професійного спілкування та набуття здобувачами освіти англомовної комунікативної компетенції.

Водночас катастрофічно обмежений обсяг аудиторних годин для іншомовної підготовки бакалаврів, як у відомчих закладах вищої освіти ДСНС України, так i у цивільних закладах, формальне ставлення здобувачів до опанування іноземної мови, відсутність мотивації та усвідомлення значущості як іншомовної компетентності, так і готовності до іншомовної професійної комунікації, передування вивчення мовної навчальної дисципліни професійноорієнтованим дисциплінам унеможливлюють набуття випускниками освітньопрофесійних програм «Цивільний захист» сформованої іншомовної компетенції, що спонукає науковців до подальшої комплексної розробки питання ефективності іншомовної підготовки у відомчих закладах вищої освіти Державної служби України з надзвичайних ситуацій.

\section{Jimepamypa:}

1. Міжнародна діяльність. Сайт Державної служби України з надзвичайних ситуацій. URL: https://www.dsns.gov.ua/ua/Mizhnarona-diyalnist.html (дата звернення: 27.10.2021)

2. Nenko Y., Yaryhina V., Vorona V. Estudo da prontidão de oficiais para interação de língua estrangeira em operações internacionais. Práxis Educacional. 2021. S. 1. V. 17. N. 46. P. 1-23. DOI: 10.22481/praxisedu.v17i46.8816. URL: https://periodicos2.uesb.br/index.php/praxis/ article/view/8816 (дата звернення: 29.10.2021)

3. Risk reducation and emergency preparedness: WHO six-year strategy for the health sector and community capacity development. World Health Organization, 2007. URL: https://www.who.int/hac / techguidance/preparedness/emergency_preparedness_eng.pdf (дата звернення: 31.10.2021)

4. Вовчаста Н.Я. Теоретичні засади концепиії професійної іншомовної підготовки майбутніх фахівиів иииільної безпеки. Наукові записки Вінницького державного педагогічного університету імені Михайла Коцюбинського. 2017. № 49. С. 42-45.

5. Ненько Ю. П. Теоретико-методологічні засади професійно орієнтованої комунікативної підготовки майбутніх офіцерів служби цивільного захисту : дис. ... д-ра пед. наук : 13.00.04. Рівне, 2018. 512 с.

6. Шихненко К. І. Теоретичні засади іншомовної підготовки фахівців державної служби України з надзвичайних ситуацій. Вісник Науково-методичного центру навчальних закладів сфери цивільного захисту. 2017. № 26. С. 89-95. URL: http://edu-mns.org.ua/img/news/7220/ VESNIK_26_2017.PDF (дата звернення: 30.10.2021)

7. Освітньо-професійна програма «Цивільний захист». Черкаський інститут пожежної безпеки імені Героїв Чорнобиля Національного університету ичивільного захисту України, 2021. URL: https://chipb.dsns.gov.ua/ua/Civilniy-zahist.html (дата звернення: 30.10.2021)

8. Постанова Кабінету Міністрів України від 23.11.2011 р. № 1341 «Про затвердження Національної рамки кваліфікацій». URL: http://zakon4.rada.gov.ua/laws/show/1341-2011-п (дата звернення: 29.10.2021)

9. Стандарт вищої освіти за спеціальністю 263 «Цивільна безпека» для першого (бакалаврського) рівня вищої освіти. Наказ Міністерства освіти і науки України від 29 жовтня 
2018p. № 1170. URL: https://mon.gov.ua/ua/npa/pro-zatverdzhennyastandartu-vishoyi-osviti-zaspecialnistyu-263-civilna-bezpeka-dlya-pershogo-bakalavrskogo-rivnyavishoyi-osviti.

10. Силабус навчальної дисципліни «Іноземна мова» (англійська) циклу загальної (обов'язкової) підготовки за першим (бакалаврським) рівнем вищої освіти галузь знань 26 «Цивільна безпека» спеціальність 263 «Цивільна безпека» за освітньо-професійною програмою «Цивільний захист». Черкаський інститут пожежної безпеки імені Героїв Чорнобиля Національного університету цивільного захисту України, 2021. URL: https://chipb.dsns.gov.ua/files/pages/ Navch_dok/CZ/\%D1\%81\%D0\%B8\%D0\%BB\%D0\%B0\%D0\%B1\%D1\%83\%D1\%81\%D0\%B8/\%D0\%9 E\%D0\%9A3_\%D0\%A1\%D0\%B8\%D0\%BB\%D0\%B0\%D0\%B1\%D1\%83\%D1\%81\%20\%D0\%86\%D0 \%9C_\%D0\%A6\%D0\%97.pdf (дата звернення: 30.10.2021)

11. Силабус навчальної дисципліни «Іноземна мова» (англійська) циклу загальної (обов'язкової) підготовки за першим (бакалаврським) рівнем вищої освіти галузь знань 26 «Цивільна безпека» спеціальність 263 «Цивільна безпека» за освітньо-професійною програмою «Цивільний захист». Національний університет цивільного захисту України, 2020. URL: http://psi.nuczu.edu.ua/images/myfolder/mov/Syllabus/TsZ/IM_TsZ_TsZ_20-21_o.pdf (дата звернення: 31.10.2021)

12. Освітньо-професійна програма «Цивільний захист». Національний технічний університет «Дніпровська політехніка», 2019. URL: https://www.nmu.org.ua/ua/content/ infrastructure/structural_divisions/science_met_dep/OPP\%20bakalavr/263\%20\%D0\%B1\%D0\%B0\% D0\%BA\%D0\%B0\%D0\%BB\%D0\%B0\%D0\%B2\%D1\%80\%20\%D0\%9E\%D0\%9F\%D0\%9F-19.pdf (дата звернення: 01.11.2021)

13. Освітньо-професійна програма «Цивільний захист». Наџіональний авіаційний університет, 2018. https://nau.edu.ua/download/Quality\%20Assurance_ukr/EKTS/OPP_2019/ FEBIT_IEB/11_263_bak.pdf

14. Освітньо-професійна програма «Цивільний захист». Національний університет «Львівська політехніка», 2021. URL: https://lpnu.ua/sites/default/files/2021/program/12905/oop2021-cbproekt.pdf (дата звернення: 01.11.2021)

\section{References:}

1. Mizhnarodna diialnist [International activities]. Sait Derzhavnoi sluzhby Ukrainy z nadzvychainykh sytuatsii - Website of the State Emergency Service of Ukraine. Retrieved from: https://www.dsns.gov.ua/ua/Mizhnarona-diyalnist.html (дата звернення: 27.10.2021) [in Ukrainian]

2. Nenko Y., Yaryhina V., Vorona V. (2021). Estudo da prontidão de oficiais para interação de língua estrangeira em operações internacionais. Práxis Educacional, S.1, V.17, 46, 1-23. DOI: 10.22481/praxisedu.v17i46.8816. Retrieved from: https://periodicos2.uesb.br/ index.php/praxis/ article/view/8816

3. Risk reducation and emergency preparedness: WHO six-year strategy for the health sector and community capacity development. (2007). World Health Organization. Retrieved from: https://www.who.int/hac/techguidance/preparedness/emergency_preparedness_eng.pdf

4. Vovchasta, N. Ya. (2017). Teoretychni zasady kontseptsii profesiinoi inshomovnoi pidhotovky maibutnikh fakhivtsiv tsyvilnoi bezpeky [Theoretical bases of the concept of professional foreign language training of future civil protection specialists]. Naukovi zapysky Vinnytskoho derzhavnoho pedahohichnoho universytetu imeni Mykhaila Kotsiubynskoho - Scientific notes of Vinnytsia State Pedagogical University named after Mykhailo Kotsyubynsky, 49, 42-45 [in Ukrainian].

5. Nenko, Yu. P. (2018). Teoretyko-metodolohichni zasady profesiino oriientovanoi komunikatyvnoi pidhotovky maibutnikh ofitseriv sluzhby tsyvilnoho zakhystu [Theoretical and methodological principles of professionally oriented communicative training of future officers of the Civil Defense Service]. Doctor's thesis. Rivne: RSHU [in Ukrainian]. 
6. Shykhnenko, K. I. (2017). Teoretychni zasady inshomovnoi pidhotovky fakhivtsiv derzhavnoi sluzhby Ukrainy $\mathrm{z}$ nadzvychainykh sytuatsii [Theoretical bases of foreign language training of specialists of the State Emergency Service of Ukraine]. Visnyk Naukovo-metodychnoho tsentru navchalnykh zakladiv sfery tsyvilnoho zakhystu [Bulletin of the Scientific and Methodological Center for Educational Institutions in the Field of Civil Defense], 26, 89-95. Retrieved from: http://edu-mns.org.ua/img/news/7220/VESNIK_26_2017.PDF [in Ukrainian]

7. Osvitno-profesiina prohrama «Tsyvilnyi zakhyst» [Educational-professional program «Civil Defense»], 2021. Cherkaskyi instytut pozhezhnoi bezpeky imeni Heroiv Chornobylia Natsionalnoho universytetu tsyvilnoho zakhystu Ukrainy [Cherkasy Institute of fire Safety named after Chornobyl Heroes of the National University of Civil Defense of Ukraine]. Retrieved from: https://chipb.dsns.gov.ua/ua/Civilniy-zahist.html [in Ukrainian]

8. Postanova Kabinetu Ministriv Ukrainy vid 23.11.2011 r. № 1341 «Pro zatverdzhennia Natsionalnoi ramky kvalifikatsii» [Resolution of the Cabinet of Ministers of Ukraine of 23.11.2011 № 1341 «On approval of the National Qualifications Framework»] Retrieved from: http://zakon4.rada.gov.ua/laws/show/1341-2011-п [in Ukrainian]

9. Standart vyshchoi osvity za spetsialnistiu 263 «Tsyvilna bezpeka» dlia pershoho (bakalavrskoho) rivnia vyshchoi osvity [Standard of higher education in specialty 263 «Civil Security» for the first (bachelor's) level of higher education]. Nakaz Ministerstva osvity i nauky Ukrainy vid 29 zhovtnia 2018 r. [Order of the Ministry of Education and Science of Ukraine dated October 29, 2018]. № 1170. Retrieved from: https://mon.gov.ua/ua/npa/pro-zatverdzhennyastandartuvishoyi-osviti-za-specialnistyu-263-civilna-bezpeka-dlya-pershogo-bakalavrskogo-rivnyavishoyiosviti [in Ukrainian]

10. Sylabus navchalnoi dystsypliny «Inozemna mova» (anhliiska) tsyklu zahalnoi (obov'iazkovoi) pidhotovky za pershym (bakalavrskym) rivnem vyshchoi osvity haluz znan 26 «Tsyvilna bezpeka» spetsialnist 263 «Tsyvilna bezpeka» za osvitno-profesiinoiu prohramoiu «Tsyvilnyi zakhyst» [Syllabus of the discipline «Foreign language» (English) of the cycle of general (compulsory) training at the first (bachelor's) level of higher education field of knowledge 26 «Civil Security» specialty 263 «Civil Security» educational-professional program «Civil Defense»], 2021. Cherkaskyi instytut pozhezhnoi bezpeky imeni Heroiv Chornobylia Natsionalnoho universytetu tsyvilnoho zakhystu Ukrainy [Cherkasy Institute of fire Safety named after Chornobyl Heroes of the National University of Civil Defense of Ukraine]. Retrieved from: https://chipb.dsns.gov.ua/files/pages/Navch_dok/CZ/\%D1\%81\%D0\%B8\%D0\%BB\%D0\%B0\%D0\% B1\%D1\%83\%D1\%81\%D0\%B8/\%D0\%9E\%D0\%9A3_\%D0\%A1\%D0\%B8\%D0\%BB\%D0\%B0\%D 0\%B1\%D1\%83\%D1\%81\%20\%D0\%86\%D0\%9C_\%D0\%A6\%D0\%97.pdf [in Ukrainian]

11. Sylabus navchalnoi dystsypliny «Inozemna mova» (anhliiska) tsyklu zahalnoi (obov'iazkovoi) pidhotovky za pershym (bakalavrskym) rivnem vyshchoi osvity haluz znan 26 «Tsyvilna bezpeka» spetsialnist 263 «Tsyvilna bezpeka» za osvitno-profesiinoiu prohramoiu «Tsyvilnyi zakhyst» [Syllabus of the discipline «Foreign language» (English) of the cycle of general (compulsory) training at the first (bachelor's) level of higher education field of knowledge 26 «Civil Security» specialty 263 «Civil Security» educational-professional program «Civil Defense»], 2020. Natsionalnyi universytet tsyvilnoho zakhystu Ukrainy [National University of Civil Defense of Ukraine]. Retrieved from: http://psi.nuczu.edu.ua/images/myfolder/mov/Syllabus/TsZ/IM_TsZ_ TsZ_20-21_o.pdf [in Ukrainian]

12. Osvitno-profesiina prohrama «Tsyvilnyi zakhyst» [Educational-professional program «Civil Defense»], 2019. Natsionalnyi tekhnichnyi universytet «Dniprovska politekhnika» [National Technical University «Dniepro Polytechnic»]. Retrieved from: https://www.nmu.org.ua/ua/content/ infrastructure/structural_divisions/science_met_dep/OPP $\% 20$ bakalavr/263\%20\%D0\%B1\%D0\%B0\% D0\%BA\%D0\%B0\%D0\%BB\%D0\%B0\%D0\%B2\%D1\%80\%20\%D0\%9E\%D0\%9F\%D0\%9F-19.pdf [in Ukrainian] 
13. Osvitno-profesiina prohrama «Tsyvilnyi zakhyst» [Educational-professional program «Civil Defense»], 2018. Natsionalnyi aviatsiinyi universytet [National Aviation University]. Retrieved from: https://nau.edu.ua/download/Quality\%20Assurance_ukr/EKTS/OPP_2019/ FEBIT_ IEB/11_263_bak.pdf [in Ukrainian]

14. Osvitno-profesiina prohrama «Tsyvilnyi zakhyst» [Educational-professional program «Civil Defense»], 2021. Natsionalnyi universytet «Lvivska politekhnika» [National University «Lviv Polytechnic»]. Retrieved from: https://lpnu.ua/sites/default/files/2021/ program/12905/oop-2021cbproekt.pdf [in Ukrainian] 